\title{
Ischemia-Reperfusion Induces Inhibition of Mitochondrial Protein Synthesis and Cytochrome c Oxidase Activity in Rat Hippocampus
}

\author{
P. RACAY, Z. TATARKOVÁ, A. DRGOVÁ, P. KAPLAN, D. DOBROTA
}

Institute of Medical Biochemistry, Jessenius Faculty of Medicine, Comenius University, Martin, Slovak Republic

Received August 22, 2007

Accepted October 18, 2007

On-line January 17, 2008

\begin{abstract}
Summary
Dysfunction of mitochondria induced by ischemia is considered to be a key event triggering neuronal cell death after brain ischemia. Here we report the effect of ischemia-reperfusion on mitochondrial protein synthesis and activity of cytochrome $c$ oxidase (EC 1.9.3.1, COX). By performing 4-vessel occlusion model of global brain ischemia, we have observed that $15 \mathrm{~min}$ of global ischemia led to the inhibition of COX subunit I (COXI) synthesis to $56 \%$ of control. After 1, 3 and $24 \mathrm{~h}$ of reperfusion, COXI synthesis was inhibited to 46,50 and $72 \%$ of control, respectively. Depressed synthesis of COXI was not a result of either diminished transcription of COXI gene or increased proteolytic degradation of COXI, since both Northern hybridization and Western blotting did not show significant changes in COXI mRNA and protein level. Thus, ischemiareperfusion affects directly mitochondrial translation machinery. In addition, ischemia in duration of $15 \mathrm{~min}$ and consequent 1,3 and $24 \mathrm{~h}$ of reperfusion led to the inhibition of COX activity to $90.3,80.3,81.9$ and $83.5 \%$ of control, respectively. Based on our data, we suggest that inhibition of COX activity is rather caused by ischemia-induced modification of COX polypeptides than by inhibition of mitochondrial translation.
\end{abstract}

\section{Key words \\ Cytochrome c oxidase - Global ischemia - Mitochondria • Translation}

\section{Corresponding author}

Peter Racay, Institute of Medical Biochemistry, Jessenius Faculty of Medicine, Comenius University, Mala Hora 4, SK-03601 Martin, Slovak Republic. Fax: +421-43-4136760. E-mail: racay@jfmed.uniba.sk

\section{Introduction}

Inhibition of global protein synthesis after brain ischemia is well known phenomenon already documented in several studies (for review see Hossmann 1993, DeGracia et al. 2002). However, little is known about the effect of brain ischemia-reperfusion injury on mitochondrial protein synthesis. Despite the involvements of mitochondria in both neuronal cell survival (Nicholls and Budd 2000) and ischemic cell death (Fiskum 2000) there is only one study dealing with the effect of brain ischemia on mitochondrial translation (Smialek and Hamberger 1970). Last two decades, mitochondria are attracting more interests due to recognition of their important role in the process of apoptosis (Nicholls and Budd 2000, Polster and Fiskum 2004) and activation of apoptosis after brain ischemia has been documented in several studies (Nitatori et al. 1995, Charriaut-Marlangue et al. 1996, Honkainiemi et al. 1996, Krajewski et al. 1999, Perez-Pinzon et al. 1999, Sugawara et al. 1999, Cao et al. 2003, Endo et al. 2006). Recent studies have postulated that apoptosis is closely linked to mitochondrial dysfunction, including disturbances of mitochondrial translation. Inhibition of mitochondrial protein synthesis led to increased sensitivity of cells to nitric oxide-induced apoptosis and to inhibition of mitochondrial respiratory chain complexes (Ramachandran et al. 2002). In turn, inhibition of respiratory chain complexes provoked the activation of mitochondrial-dependent apoptotic machinery by direct triggering of cytochrome c release from mitochondria (Clayton et al. 2005) or indirect 
induction of Bax-dependent apoptosis through mitochondrial oxidative damage (Perier et al. 2005). Since core subunits of crucial mitochondria respiratory chain complexes are encoded by mitochondrial DNA, inhibition of mitochondrial protein synthesis might have a great impact on brain functions. This has been documented in some types of mitochondrial encephalopathies, which are often associated with point mutations in mitochondrial genes and consequent disturbance in synthesis and functions of respiratory chain complexes (Taanman 1999, Wallace 1999, Chomyn et al. 2000, Smeitink et al. 2001, Tryoen-Thot et al. 2003). Despite these important facts, little is known about the effect of ischemia on mitochondrial translation. To our knowledge, there is only one study dealing with the effect of global brain ischemia on mitochondrial translation (Smialek and Hamberger 1970) showing that ischemia led to an increase of both mitochondrial translation rate and activity of COX. Therefore the main aim of our study was to investigate the effect of global brain ischemia and consequent reperfusion on mitochondrial protein synthesis in more details. In addition to mitochondrial translation, the effect of ischemia-reperfusion on transcription of mitochondrial DNA, mitochondrial protein levels and activity of COX was investigated.

\section{Methods}

\section{Ischemia-reperfusion}

Animal studies were performed under a protocol approved by the State Veterinary and Food Department of Slovak Republic. A total of 30 adult male Wistar rats from the breeding house of the Institute of Experimental Pharmacology of Slovak Academy of Science (Dobrá voda, Slovak Republic) weighing 320-380 g were used. All animals were maintained on a $12 / 12 \mathrm{~h}$ light/dark cycle. Food and water were available ad libitum until the beginning of the experiment. The animals were anesthetized by inhalation of $2 \%$ halothane, $30 \% \mathrm{O}_{2}$ and $68 \% \mathrm{~N}_{2} \mathrm{O}$ mixture. Transient global cerebral ischemia was produced using the four-vessel occlusion model. Briefly, on day 1, both vertebral arteries were irreversibly occluded by coagulation through the alar foramina. On day 2 , the animals were again anesthetized by inhalation of $2 \%$ halothane, $30 \% \mathrm{O}_{2}$ and $68 \% \mathrm{~N}_{2} \mathrm{O}$ mixture followed with surgical preparation of both common carotid arteries. Two min before carotid occlusion, the halothane was removed from the mixture. Then, both common carotid arteries were occluded for $15 \mathrm{~min}$ by small surgical clips. Body temperature was maintained using a homoeothermic blanket. Reperfusion in duration 1,3 , or $24 \mathrm{~h}$ was induced by a release of clips. After 15 min of ischemia and 1,3 , or $24 \mathrm{~h}$ of reperfusion following $15 \mathrm{~min}$ of global ischemia, animals were sacrificed by decapitation and both hippocampi were dissected and processed immediately. Control animals underwent the same procedure except of carotid occlusion. Isolations of mitochondria and measurements of mitochondrial translations were carried out on experimental and control tissue simultaneously to reduce variability. Numbers of analyzed animals per experimental group are indicated in figure legends.

\section{Isolation of mitochondria}

A protocol adapted from Lee et al. (1993) with some modifications was used to prepare metabolically active mitochondria from rat hippocampus. Dissected tissue was homogenized in ice-cold homogenization buffer (25 mM 4-morpholinepropanesulfonic acid, pH 7.4, $250 \mathrm{mM}$ sucrose, $4 \mathrm{mM} \mathrm{MgCl}_{2}, 0.05$ mM EGTA) using Potter Teflon-glass homogenizer. Homogenate was centrifuged at $400 \times \mathrm{g}$ for $5 \mathrm{~min}$ and supernatant was collected. Supernatant was then centrifuged at $12000 \mathrm{x} g$ for $10 \mathrm{~min}$. Resulting sediment was resuspended in homogenization buffer and centrifuged at $12000 \mathrm{x} g$ for 10 min. Final sediment was resuspended in homogenization buffer and stored on ice. Protein concentration was determined by protein Dc assay kit (Bio-Rad).

\section{Western blot analysis}

Membrane protein fractions were prepared by homogenization of tissue in homogenization buffer using a Potter Teflon-glass homogenizer. Cell membranes were sedimented by centrifugation at $30000 \mathrm{x} \mathrm{g}$ for $20 \mathrm{~min}$. Membrane pellets were resuspended in homogenization buffer and membrane proteins were solubilized by addition of $20 \%$ sodium dodecylsulfate (SDS) to final concentration of $10 \%$. Protein concentration was determined by protein Dc assay kit (Bio-Rad). Proteins were separated by sodium dodecylsulfate-polyacrylamide gel electrophoresis (SDS-PAGE) using $12.5 \%$ acrylamide-bis acrylamide gels, and then transferred on nitrocellulose membranes using a semi-dry transfer protocol. The membranes were controlled for even load and possible transfer artifacts by staining with Ponceau Red solution. After blocking with $2.5 \%$ of Topo-block 
(Fluka) solution in Tris-buffered saline with addition of $0.05 \%$ of Tween 20 (TBS-T), membranes were incubated with primary antibodies against either COXI ( $1 \mu \mathrm{g} / \mathrm{ml} 1 \mathrm{D} 6$ Molecular Probes) and cytochrome c oxidase subunit $\mathrm{Vb}(\mathrm{COXVb})(2 \mu \mathrm{g} / \mathrm{ml}$, 6E9 Molecular Probes) for $90 \mathrm{~min}$ and cytochrome c oxidase subunit II (COXII) $(2.5 \mu \mathrm{g} / \mathrm{ml} 12 \mathrm{C} 4$ Molecular Probes) for $5 \mathrm{~h}$ at room temperature. All used antibodies were dissolved in TBS-T solution containing $1 \%$ of protease-free bovine serum albumin (BSA). Incubation of membranes with primary antibodies was followed by extensive washing using TBS-T solution and consequently by incubation of membranes with biotinylated anti-mouse antibodies (1:10000 in TBS-T, Vector Laboratories). After washing, membranes were incubated with avidin-biotin conjugated peroxidase (Vector Laboratories) solution in TBS-T, washed again in TBS-T solution four times $15 \mathrm{~min}$ and then incubated in SuperSignal West Pico Chemiluminescent Substrate (Pierce) solution for $1 \mathrm{~min}$. The bands corresponding to particular proteins were visualized by exposition on Biomax MR film (Kodak). The pictures were digitalized and the bands were integrated using GeneTools software (SynGene).

\section{RNA isolation and Northern blot analysis}

Total RNA was isolated from rat hippocampi using the Trizol reagent (Invitrogen) following the manufacturer's protocol. Total RNA $(5 \mu \mathrm{g})$ was separated by denaturing electrophoresis on formaldehydecontaining $1.2 \%$ agarose gels, then transferred on positively charged nylon membranes (Roche) using the capillary downstream method (Chomczynski 1992). Membranes were controlled for even load and possible transfer artifacts by staining with methylene blue solution. The position of $18 \mathrm{~S}$ and $28 \mathrm{~S}$ rRNA was marked on the membranes in order to estimate molecular sizes of particular signals. Membranes were prehybridized in ExpressHyb solution (Clontech) for $30 \mathrm{~min}$ at $60{ }^{\circ} \mathrm{C}$ and then hybridized with digoxigenin-labeled cDNA probe for $60 \mathrm{~min}$ at $60{ }^{\circ} \mathrm{C}$. The COXI probe used in the study was synthesized by amplification of rat brain cDNA using the PCR probe digoxigenin synthesis kit (Roche) applying the manufacturer's protocol. Specific front 5' - CGA GCC TAC TTT ACA TCT GCC-3' and reverse 5'-GAG TAA CGA CGA GGT ATC CCT-3' primers were used to amplify part of COXI cDNA. After hybridization, membranes were first washed twice with $0.1 \%$ SDS in double saline sodium citrate buffer (SSC, $0.3 \mathrm{M} \mathrm{NaCl}, 30 \mathrm{mM}$ sodium citrate, $\mathrm{pH}=7.0$ ) for $5 \mathrm{~min}$ at room temperature. The next step comprised a double washing with $0.1 \%$ SDS in $0.1 \mathrm{xSC}(0.015 \mathrm{M} \mathrm{NaCl}$ $1.5 \mathrm{mM}$ sodium citrate, $\mathrm{pH} 7.0$ ) for $15 \mathrm{~min}$ at $58{ }^{\circ} \mathrm{C}$. After washing, membranes were shortly rinsed in maleic acid buffer (0.1 M maleic acid, 0.15 $\mathrm{M} \mathrm{NaCl}, \mathrm{pH} 7.5)$ and then blocked in $1 \%$ blocking reagent (Roche) solution in maleic acid buffer for $30 \mathrm{~min}$ at room temperature. Membranes were then incubated with anti-digoxigenin alkaline phosphatase conjugated antibodies (1:4000, Roche) for $30 \mathrm{~min}$. Membranes were washed twice with $3 \%$ Tween-20 solution in maleic acid buffer for $15 \mathrm{~min}$ and then preincubated in detecting buffer $(0.1 \mathrm{M}$ Tris$\mathrm{HCl}, 0.1 \mathrm{M} \mathrm{NaCl}, \mathrm{pH} 9.5$ ) for $5 \mathrm{~min}$. Finally, membranes were incubated in detecting buffer-containing CDP-star substrate (1:100, Roche). The bands corresponding to COXI mRNA were visualized by exposing of Northern blot to Biomax (Kodak) film. The pictures were digitalised and the bands were integrated using GeneTools software (SynGene).

\section{In vitro translation}

Mitochondrial protein synthesis was performed according to McKee et al. (1990) with some modifications. Mitochondrial translation was initiated by resuspending of isolated mitochondria $(3.6 \mathrm{mg} / \mathrm{ml}$ of mitochondrial protein) in a prewarmed translation buffer (the final composition of $0.05 \mathrm{ml}$ of translation mixture was: $20 \mathrm{mM}$ 4-morpholine-propanesulfonic acid $\mathrm{pH}$ 7.4, $90 \mathrm{mM}$ sucrose, $90 \mathrm{mM} \mathrm{KCl}, 5 \mathrm{mM} \mathrm{MgCl} 22.5 \mathrm{mM}$ $\mathrm{KH}_{2} \mathrm{PO}_{4} 16 \mathrm{mM}$ ADP, $5 \mathrm{mM}$ succinate, $5 \mathrm{mM}$ pyruvate, $0.02 \mathrm{mM}$ EGTA, $0.05 \mathrm{mM}$ unlabeled amino acids (except of methionine), $0.5 \mathrm{mg} / \mathrm{ml}$ fatty acid free BSA, $0.1 \mathrm{mg} / \mathrm{ml}$ cycloheximide and $0.74 \mathrm{MBq}$ of $\left[{ }^{35} \mathrm{~S}\right]$-methionine (ICN)). Translation mixture was then incubated at $30^{\circ} \mathrm{C}$. At the indicated time intervals translation was analyzed either by determination of $\left[{ }^{35} \mathrm{~S}\right]$-methionine incorporation or by SDS-PAGE (see Figure legend).

\section{Measurement of cytochrome c oxidase activity}

Activity of cytochrome c oxidase was measured by monitoring of oxidation of ascorbate reduced cytochrome c. Membrane proteins were resuspended in reaction buffer $(50 \mathrm{mM}$ Tris $\mathrm{pH}=8.0,0.01 \%$ n-dodecyl $\beta$-D-maltoside). The reaction was initialized by addition of reduced cytochrome $\mathrm{c}$ to the final concentration of $0.05 \mathrm{mmol} / \mathrm{l}$. Oxidation of cytochrome c was monitored spectrophotometrically at $550 \mathrm{~nm}$ by UltrospecIII (Pharmacia-Amersham) and the rate of oxidation was calculated from the slope of absorbance dependence on 


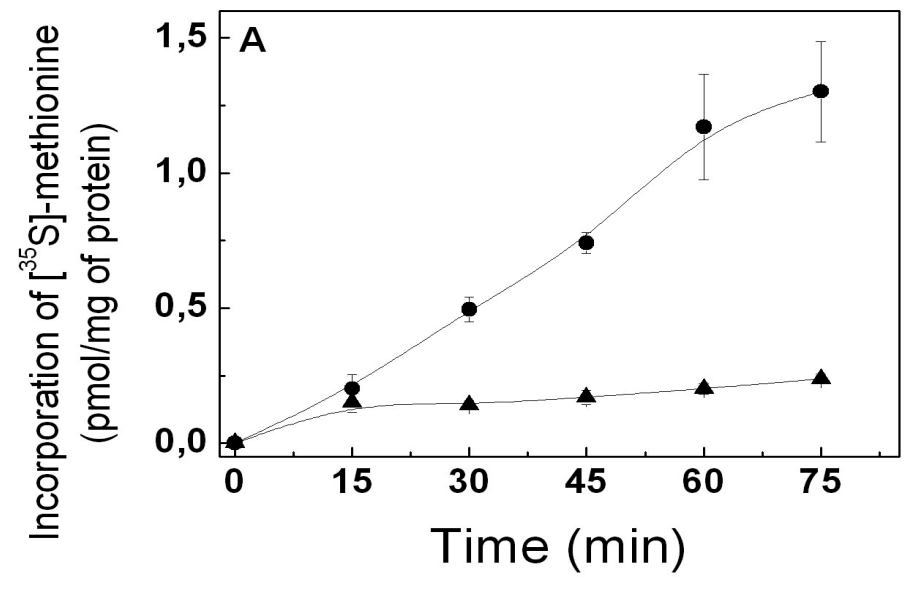

B

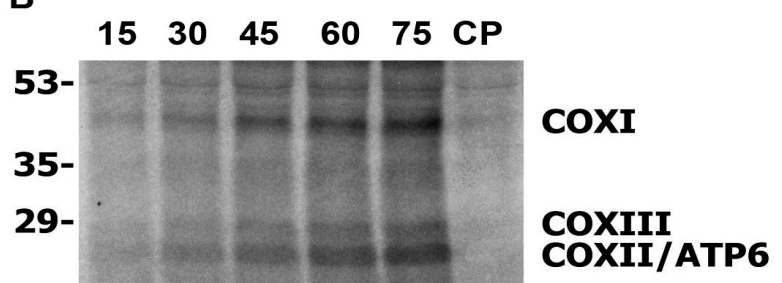

14-

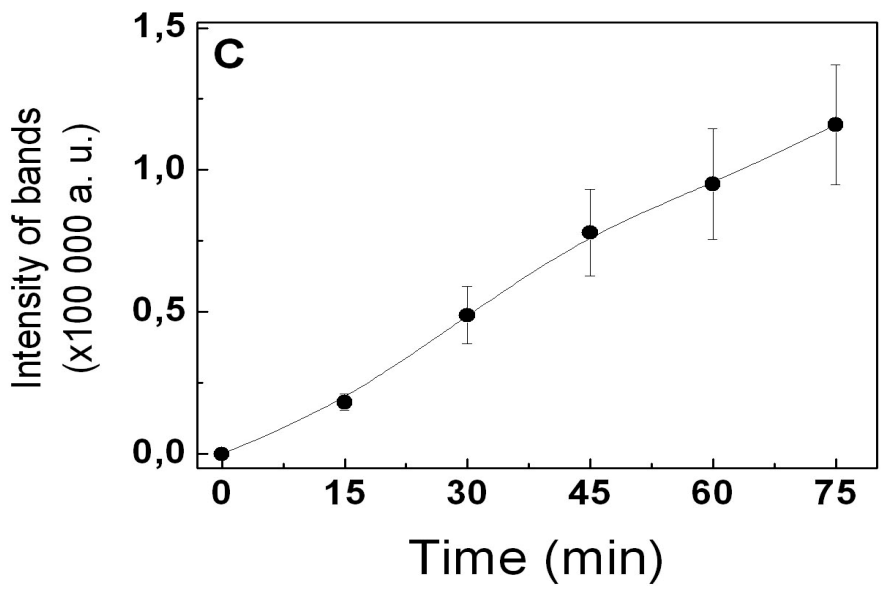

Fig. 1. Time course of mitochondrial protein synthesis. A) Time course of $\left[{ }^{35} \mathrm{~S}\right]$-methionine incorporation in the absence $(\bullet)$ and presence of 0.05 $\mathrm{mg} / \mathrm{ml}$ of chloramphenicol ( $\boldsymbol{\Delta})$. Mitochondria isolated from rat hippocampus were incubated for 15, 30, 45, 60 and 75 min in translation mixture as described in Material and Methods. Protein synthesis rates were determined by measuring of $\left[{ }^{35} \mathrm{~S}\right]$-methionine incorporation by liquid scintillation counting. Aliquots of translation mixture (corresponding to $0.02 \mathrm{mg}$ of mitochondrial proteins) were dissolved in $1 \mathrm{M} \mathrm{NaOH} / 2 \%$ hydrogen peroxide and incubated at $37^{\circ} \mathrm{C}$ for $10 \mathrm{~min}$. At the end of the incubation, $2.25 \mathrm{ml}$ of ice-cold $25 \%$ trichloroacetic acid/2 \% casamino acid (BD Science) were added to precipitate the translation products. The mixture was further incubated on ice for 30 min and then immediately filtered through membrane filters (Millipore HA, $0.45 \mu \mathrm{m}$ ) Filters were washed with $4 \times 5 \mathrm{ml}$ of ice-cold washing solution (5\% trichloroacetic acid) and dried. Radioactivity was measured by liquid scintillation spectrometer TriCarb 2200 CA. Number of moles of incorporated $\left[{ }^{35} \mathrm{~S}\right]$-methionine per $\mathrm{mg}$ of mitochondrial protein was calculated for each time point. Results are presented as mean \pm standard deviation of three independent experiments. B) Electrophoretic patterns of newly synthesized mitochondrial translation products after incubation of mitochondria in translation mixture for 15, 30, 45,60 and $75 \mathrm{~min}$ in the absence or $75 \mathrm{~min}$ in the presence of $0.05 \mathrm{mg} / \mathrm{ml}$ of chloramphenicol (CP). Mitochondria isolated from rat hippocampus were incubated for 15, 30, 45, 60 and $75 \mathrm{~min}$ in translation mixture as described in Material and Methods. Translation was terminated by addition of 6X SDS-PAGE sample buffer (300 mM Tris-HCl $\mathrm{pH}=6.8,300 \mathrm{mM}$ dithioerythritol, $12 \% \mathrm{SDS}, 60 \%$ glycerol, $0.6 \%$ bromophenol blue) and consequent incubation at 95 ${ }^{\circ} \mathrm{C}$ for $5 \mathrm{~min}$. The products of translation were separated by SDS-PAGE. Aliquots of translation mixture (corresponding to $0.05 \mathrm{mg}$ of mitochondrial proteins) were loaded on 12.5 $\%$ acrylamide-bis acrylamide gels. Synthesized proteins were visualized by exposition of dried gels to Biomax film (Kodak). Molecular mass in $\mathrm{kDa}$ of standard proteins is indicated. C) Semi-quantitative analysis from three independent experiments. Resulted autoradiograms were digitalized and the intensities of particular bands for each time point were integrated using GeneTools software (SynGene). Results are presented as mean \pm standard deviation of three independent experiments. incubation time using the value of $19.6 \mathrm{M}^{-1} \mathrm{~cm}^{-1}$ as molar extinction coefficient of oxidized cytochrome $\mathrm{c}$ at $550 \mathrm{~nm}$. The net value of the complex IV activity was calculated by subtracting the rate of cytochrome c oxidation determined in the presence of $7.5 \mathrm{mM}$ sodium azide (non-specific cytochrome c oxidation) from that obtained in the absence of sodium azide (total cytochrome c oxidation). COX activities are expressed as the number of nanomoles of oxidized cytochrome $\mathrm{c}$ per $\mathrm{mg}$ of protein per min.

\section{Statistical analysis}

Statistical analyses were done using GrafPhad InStat V2.04a (GrafPhad Software). For the comparison of ischemia-induced changes either one-way or two-way
ANOVA test (see figure legend) was performed. Additionally, Tukey's test was carried out to demonstrate significant differences between data. Significance levels were set at $p<0.05$.

\section{Results}

The main aim of our work was to study the effect of global brain ischemia-reperfusion on mitochondrial protein synthesis in more details. Based on previous works (McKee et al. 1990), we have performed in vitro translation using mitochondria isolated from rat hippocampus and $\left[{ }^{35} \mathrm{~S}\right]$-methionine labeling. Incorporation of $\left[{ }^{35} \mathrm{~S}\right]$-methionine into trichloroacetic acid-insoluble material was linear within at least $75 \mathrm{~min}$ 


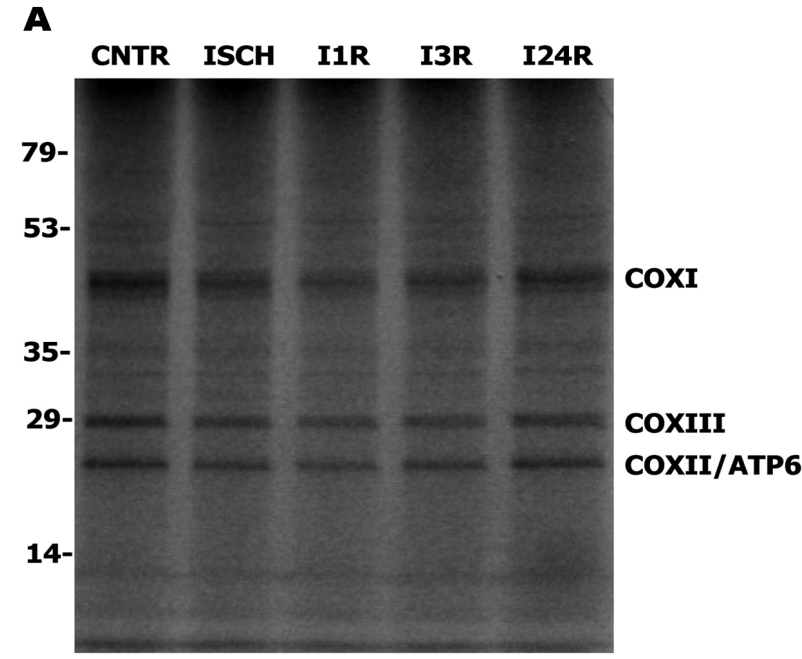

$\mathbf{B}$

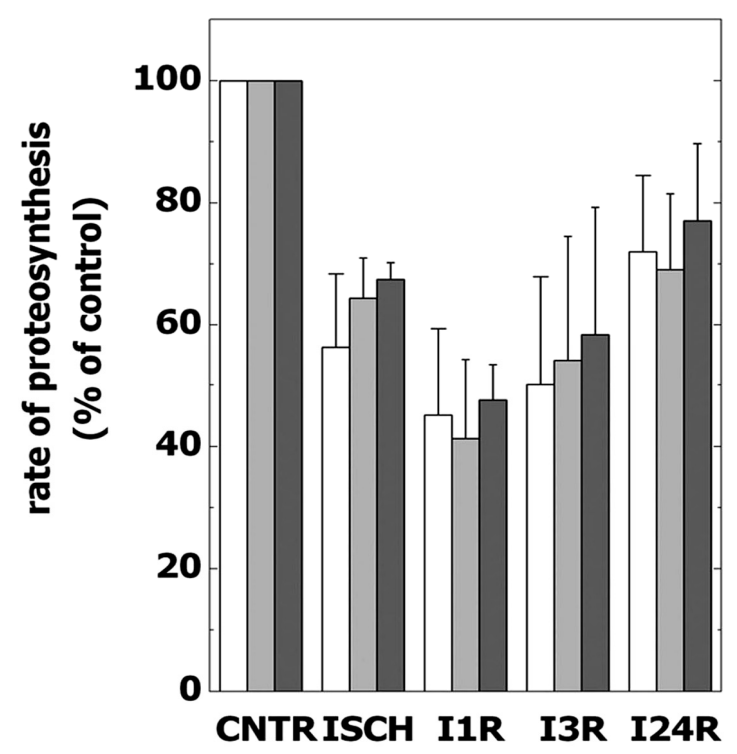

Fig. 2. Effect of ischemia-reperfusion on mitochondrial protein synthesis. A) Electrophoretic patterns of newly synthesized mitochondrial translation products. Mitochondria isolated from hippocampus of control animals (CNTR), animals subjected to $15 \mathrm{~min}$ of global ischemia (ISCH) and animals subjected to $15 \mathrm{~min}$ of global ischemia followed with reperfusion in duration of 1 (I1R), 3 (I3R) and 24 (I24R) h were incubated for $1 \mathrm{~h}$ in translation mixture as described in Material and Methods. Translation was terminated by addition of $6 \mathrm{X}$ SDS-PAGE sample buffer and consequent incubation at $95{ }^{\circ} \mathrm{C}$ for $5 \mathrm{~min}$. The products of translation were separated by SDS-PAGE. Aliquots of translation mixture (corresponding to $50 \mu \mathrm{g}$ of mitochondrial proteins) were loaded on $12.5 \%$ acrylamide-bis acrylamide gels. Synthesized proteins were visualized by exposition of dried gels to Biomax film (Kodak). Molecular mass in $\mathrm{kDa}$ of standard proteins is indicated. B) Semi-quantitative analysis from 3 animals per experimental group and samples were quantified from 3 independent SDS-PAGE separations. Resulted autoradiograms were digitalized and the intensities of bands corresponding to COXI, COXIII and COXII/ATP6 were integrated using GeneTools software (SynGene). Levels of COXI, COXIII and COXII/ATP6 in control group were set to be $100 \%$. Results are presented as mean \pm S.E.M. For the comparison of ischemia-induced changes two-way ANOVA test was performed. Additionally, Tukey's test was carried out to demonstrate significant differences between data. $P$ values calculated with Tukey's test are COXI: $p<0.01$ (CNTR vs. ISCH), $p<0.001$ (CNTR vs. I1R), $p<0.001$ (CNTR vs. I3R) and $p>0.05$ (CNTR vs. I24R); COXIII: $p<0.05$ (CNTR vs. ISCH), $p<0.001$ (CNTR vs. I1R), $p<0.01$ (CNTR vs. I3R) and $p>0.05$ (CNTR vs. I24R); COXII/ATP6: $p<0.05$ (CNTR vs. ISCH), $p<0.001$ (CNTR vs. I1R), $p<0.01$ (CNTR vs. I3R) and $\mathrm{p}<0.05$ (CNTR vs. I24R). and was negligible in the presence of $0.05 \mathrm{mg} / \mathrm{ml}$ chloramphenicol, which is strong inhibitor of mitochondrial protein synthesis (Fig. 1A). Average rate of $\left[{ }^{35} \mathrm{~S}\right]$-methionine incorporation $(1.13 \pm 0.04 \mathrm{pmol} / \mathrm{mg}$ of protein/h) was approximately one order of magnitude smaller than that obtained for global protein synthesis (Garcia et al. 2004). Thus despite the use of cycloheximide as inhibitor of cytoplasmic translation, the results of mitochondrial protein synthesis might be significantly influenced by cytoplasmic translation. To avoid misinterpretations, we have also performed electrophoretic analysis of translation products. Analysis of labeled mitochondrial translation products demonstrated that bona fide mitochondrial peptides were synthesized (Fig. 1B). We have identified all three subunits of COX encoded by mitochondrial DNA (COXI, COXII and COXIII) and subunit 6 of mitochondrial ATPase (ATP6) by comparison of our results to previously published data (Polosa and Attardi 1991).

These proteins were not detected if translation was performed in the presence of $0.05 \mathrm{mg} / \mathrm{ml}$ of chloramphenicol (Fig. 1B). In order to quantify translation based on electrophoretic analysis, resulted radiograms were digitalized and the intensities of particular bands at different time points were integrated. The results of semi-quantitative analysis showed that intensities of bands are linear at least within $75 \mathrm{~min}$ (Fig. 1C). Based on these results, we have investigated 


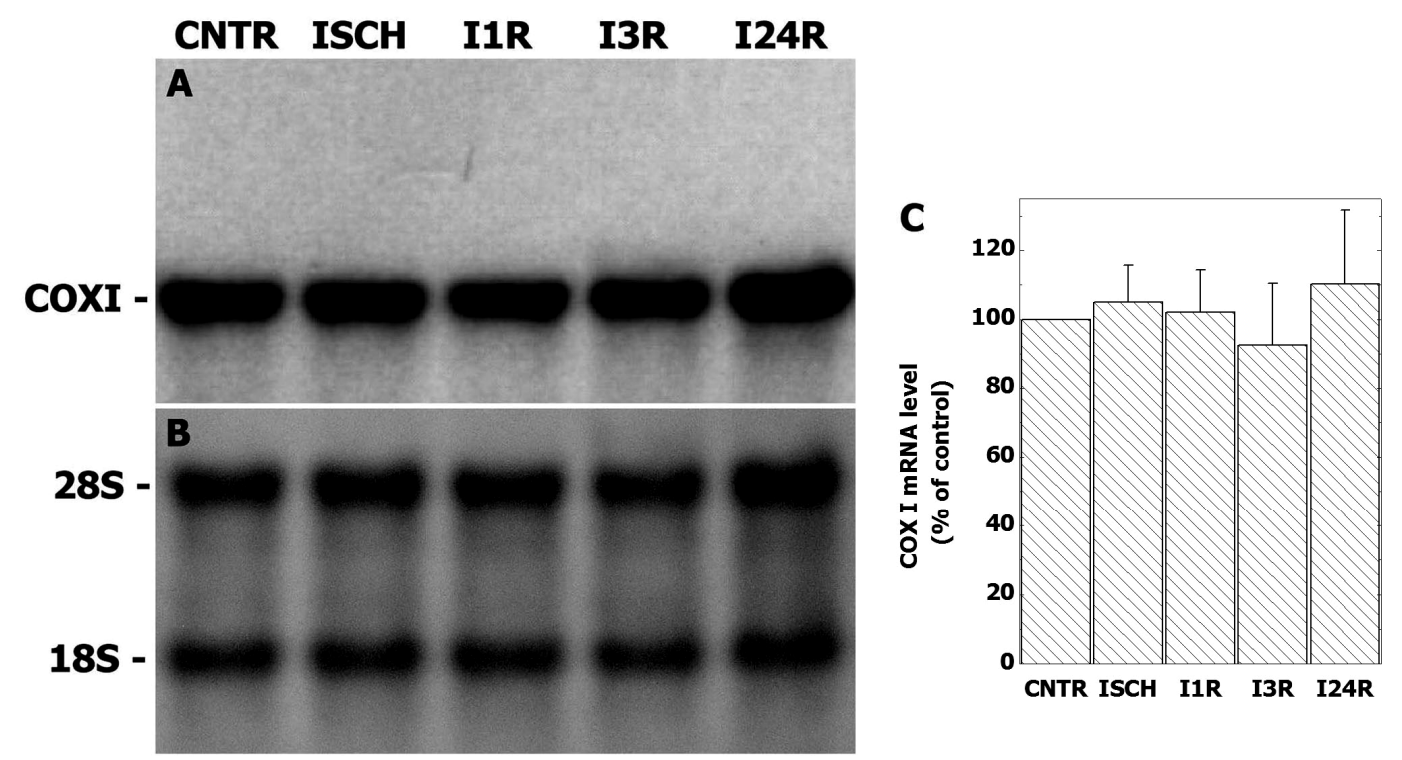

Fig. 3. Effect of ischemia-reperfusion on COXI mRNA level. A) Representative Northern blot of four independent experiments. Total RNA isolated from hippocampus of control animals (CNTR), animals subjected to 15 min of global ischemia (ISCH) and animals subjected to $15 \mathrm{~min}$ of global ischemia followed with reperfusion in duration of 1 (I1R), 3 (I3R) and 24 (I24R) $\mathrm{h}$ was analyzed by Northern blot as described in Material and Methods. No significant differences in the COXI mRNA levels were detected. B) Staining of membrane by methylene blue used as a loading control. C) Semi-quantitative analysis of COXI mRNA from four independent experiments. Results are presented as mean \pm S.E.M. For the comparison of ischemia-induced changes one-way ANOVA test was performed.

the effect of ischemia-reperfusion on mitochondrial protein synthesis by performing densitometric analysis of radiograms obtained after electrophoretic analysis of mitochondrial translation in duration of 60 min (Fig. 2A). Our results showed that $15 \mathrm{~min}$ of global ischemia led to the inhibition of COXI synthesis to $56 \%$ of control $(p<0.01)$ (Fig. 2B). Rates of COXI synthesis observed 1 and $3 \mathrm{~h}$ after $15 \mathrm{~min}$ of global ischemia were $46 \%$ $(\mathrm{p}<0.001)$ and $50 \%(\mathrm{p}<0.001)$ of control, respectively. Reperfusion in duration of $24 \mathrm{~h}$ following $15 \mathrm{~min}$ of global ischemia led to partial recovery of COXI synthesis to $72 \%(\mathrm{p}>0.05)$ of control. The extent COXIII and COXII/ATP6 synthesis inhibition is comparable to the extent of COXI synthesis inhibition (Fig. 2B).

In order to investigate whether depressed mitochondrial translation is not a result of diminished transcription we have estimated the level of COXI mRNA. We have focused our attention to this subunit since ischemia-induced decrease of COXI mRNA level has been documented in hippocampal CA1 neurons by in situ hybridisation (Abe et al. 1998). However, by performing Northern hybridization, we did not reveal significant changes in COXI mRNA level after ischemia as well as after all investigated intervals of reperfusion following $15 \mathrm{~min}$ of global ischemia (Fig. 3).

In addition to the rate of transcription and translation, level of proteins is significantly affected by velocity of protein turnover. Increased protein degradation due to stimulation of different proteolytic enzymes was documented after ischemia-reperfusion in several studies (for review see Lipton 1999). Degradation of COXII subunit by mitochondrial protease Lon was also reported under the conditions of endoplasmic reticulum stress (Hori et al. 2002), which is often implicated as pathophysiological mechanisms associated with brain ischemia-reperfusion injury (Paschen and Doutheil 1999). Therefore, we have performed semiquantitative Western blot analysis of the level of COXI and COXII proteins. However, our results did not show any significant changes in both COXI and COXII protein levels after ischemia in duration of $15 \mathrm{~min}$ as well as after 1,3 and $24 \mathrm{~h}$ of reperfusion following $15 \mathrm{~min}$ of global ischemia (Fig. 4). We have also investigated the effect of ischemia-reperfusion on expression of regulatory $\mathrm{COXVb}$ subunit (Burke and Poyton 1998), which is encoded by nuclear DNA. As it is shown in Figure 4, we did not observe significant changes in the level of protein after ischemia and after all investigated intervals of reperfusion.

Since subunits of COX were identified as mitochondrial translation products, the effect of ischemiareperfusion on activity of COX was investigated as well. We have observed that global ischemia in duration of 15 min led to a significant inhibition of COX activity to 

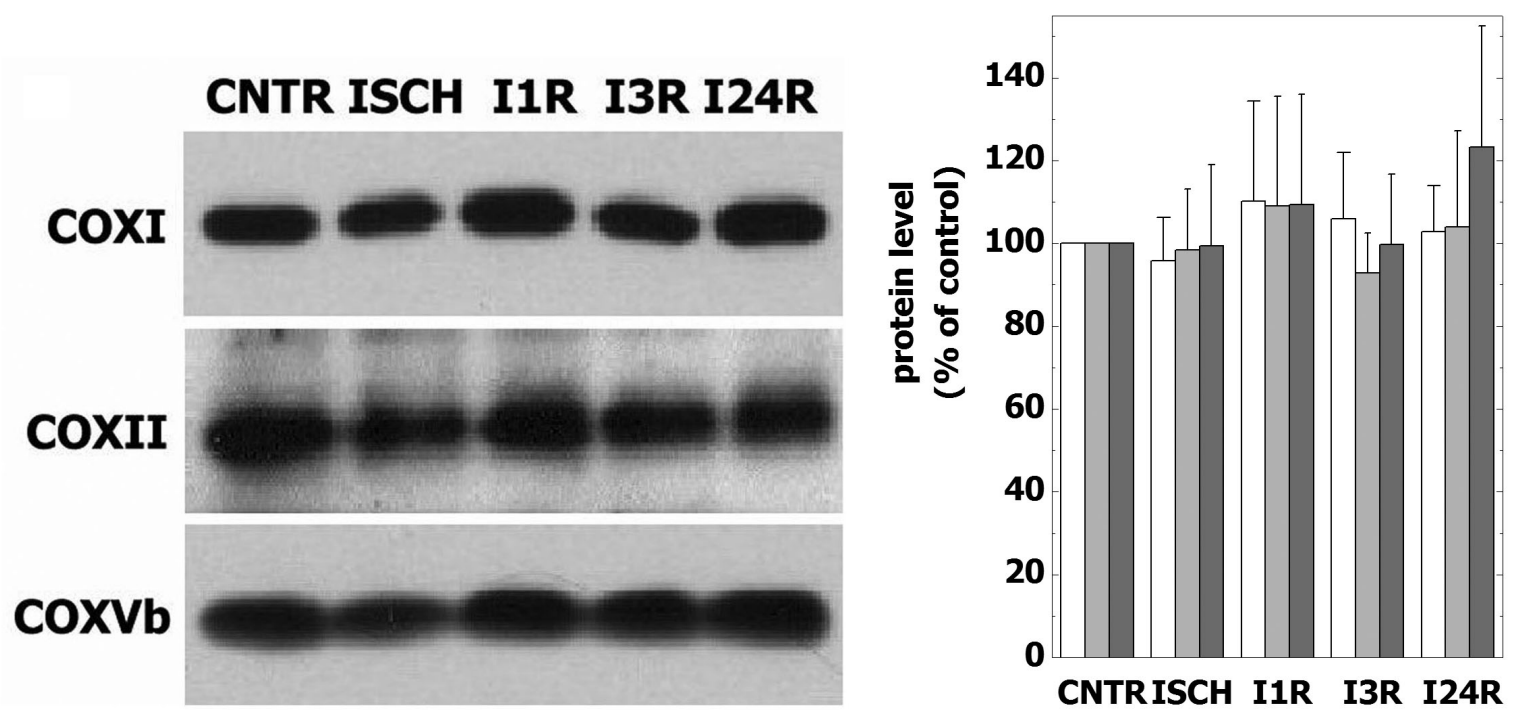

Fig 4. Effect of ischemia-reperfusion on COXI, cOXII and COXVb protein level. Representative Western blots of COXI, COXII and $\mathrm{COXVb}$ and semi-quantitative analysis from four independent experiments. Membrane proteins were isolated from the hippocampus of control animals (CNTR), animals subjected to $15 \mathrm{~min}$ of global ischemia (ISCH) and animals subjected to 15 min of global ischemia followed with reperfusion in duration of 1 (I1R), 3 (I3R) and 24 (I24R) $\mathrm{h}$ and analyzed by Western blot as described in Material and Methods. No significant differences in the COXI, COXII and COXVb protein levels were detected. Results are presented as mean \pm S.E.M. For the comparison of ischemia-induced changes one-way ANOVA test was performed.

$90.3 \%$ of control $(\mathrm{p}<0.001)$. Similarly to the inhibition of mitochondrial protein synthesis, the minimal COX activity, $80.3 \%$ of control $(\mathrm{p}<0.001)$, was observed one hour following $15 \mathrm{~min}$ of global ischemia. Reperfusions in duration of 3 and $24 \mathrm{~h}$ led to inhibition of COX activity to $81.9 \%(\mathrm{p}<0.001)$ and $83.5 \%(\mathrm{p}<0.001)$ of control, respectively (Fig. 5).

\section{Discussion}

The main finding of our study was that ischemia-reperfusion affects directly mitochondrial translation and induces inhibition of mitochondrial protein synthesis in rat hippocampus. Three sites of protein synthesis (cytoplasm, rough endoplasmic reticulum and mitochondria) were recognized in mammalian cells (Kapp and Lorsch 2004) including neurons. The ischemia-induced inhibition of global protein synthesis has already been documented in several studies (Bodsch and Takahashi 1984, Kiessling et al. 1986, Thilmann et al. 1986, Nowak 1990, Hossmann 1993). To our knowledge, there is only one study dealing with effect of global brain ischemia on mitochondrial translation (Smialek and Hamberger 1970). Unlike our study, they showed that ischemia led to increased mitochondrial translation and activity of COX. The discrepancies between results could be attributed to the different models of ischemia, since bilateral occlusion of common carotid arteries of rabbits without occlusion of vertebral arteries was used in previous study.

Decreased mRNA level due to depressed transcription of particular gene or decreased mRNA stability is often the reason of decreased translation. In fact, ischemia-induced decline of COXI mRNA was observed in pyramidal CA1 neurons using in situ hybridization (Abe et al. 1993, Abe et al. 1998). In addition, down-regulation of mitochondrial transcription and mRNA in both mitochondrial-encoded proteins (COXI and II) and nuclear-encoded proteins (COXIV and $\mathrm{Vb})$ was observed in PC12 cells exposed to hypoxia for 10 h (Vijayasarathy et al. 2003). Reoxygenation nearly completely reversed hypoxia-mediated changes in COX mRNA contents and rate of mitochondrial transcription. However, our Northern blot analysis did not reveal significant changes in mRNA of COXI, indicating that depressed mitochondrial translation observed in our study was not due to diminished transcription of mitochondrial genes. Unaltered level of COXI mRNA observed in our study represents only apparent discrepancy to the results published by Abe et al. (1993, 1998). Since COX is expressed ubiquitously and CA1 pyramidal neurons represent only a small fraction of rat hippocampus cells, 


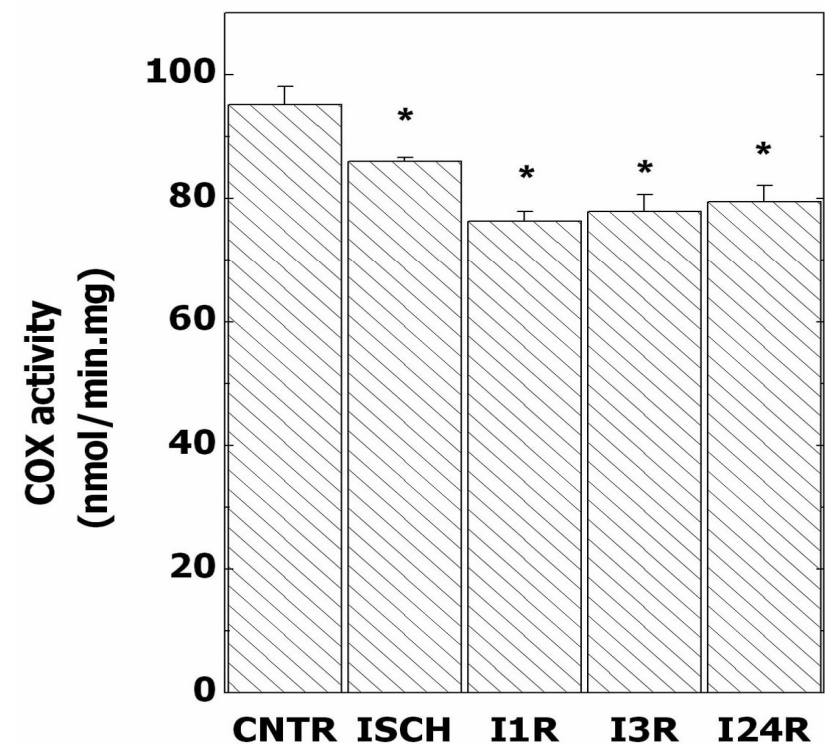

Fig. 5. Effect of ischemia-reperfusion on cox activity. Membrane proteins were isolated from hippocampus of control animals (CNTR), animals subjected to $15 \mathrm{~min}$ of global ischemia (ISCH) and animals subjected to $15 \mathrm{~min}$ of global ischemia followed with reperfusion in duration of 1 (I1R), 3 (I3R) and 24 (I24R) hours. Activity of cytochrome c oxidase was determined as described in Materials and Methods. Results are presented as mean \pm SD of four independent experiments performed in duplicate. For the comparison of ischemia-induced changes oneway ANOVA test was performed. Additionally, Tukey's test was carried out to demonstrate significant differences between data. $* \mathrm{P}<0.001$.

it is likely that changes observed selectively in CA1 cells are masked by unaltered level of COXI mRNA in the rest of hippocampal cells. Increased proteolysis would be another plausible explanation of decreased level of mitochondrial proteins detected after PAGE analysis. Since our Western blot analysis did not reveal any changes in COXI and COXII protein level, we assume that decreased level of newly synthesized COXI and COXII subunits observed after ischemia was not due to ischemia-induced stimulation of their proteolytic degradation but due to decreased rate of their synthesis. This finding was in particular important with respect to COXII. Degradation of COXII by mitochondrial protease Lon was reported under the conditions of endoplasmic reticulum stress (Hori et al. 2002), which is often implicated in pathophysiological mechanisms associated with brain ischemia-reperfusion injury (Paschen and Doutheil 1999). The observed differences between depression of mitochondrial translation and unaltered level of COXI and COXII might be attributed to stability of these proteins.

Based on unaltered transcription and protein degradation, our results indicate that brain ischemia- reperfusion affects directly mitochondrial translation machinery. Modifications of some translation factors has been recognized as the major cause of ischemia/reperfusion-induced depression of cytosolic translation (Hu and Wieloch 1993, Burda et al. 1994, Neumar et al. 1995, DeGracia et al. 1996, Neumar et al. 1998, Martin de la Vega et al. 2001, Althausen et al. 2001, Mengesdorf et al. 2002). Mitochondrial translation is governed by translation factors, which are derived from bacterial translation factors sharing 30-40\% homology to mammalian cytosolic translation factors (Ma and Spremulli 1995). Whether ischemia-reperfusion affects the mitochondrial translation factors in the same way as cytosolic translation factors is unclear and remains to be further investigated. Cytoplasmic translation is almost completely inhibited by ischemia-reperfusion (Hossmann 1993). Thus, our results showing moderate inhibition of mitochondrial protein synthesis might indicate that distinct mechanisms are involved in ischemia/ reperfusion-induced inhibition of cytoplasmic and mitochondrial translation.

In addition, we showed that ischemia induced inhibition of COX activity without significant changes of COXI and COXII proteins. It was demonstrated by a histochemical method that COX activity without exogenous cytochrome $\mathrm{c}$ decreased in the CA1 neurons from 1 hour after ischemia, but was restored by the addition of exogenous cytochrome $\mathrm{c}$ in the following $6 \mathrm{~h}$ after ischemia (Nakatsuka et al. 2000). These results suggest that it is not COX activity but endogenous cytochrome $\mathrm{c}$ that is changed in the early phase after ischemia, and that COX activity begins to decrease $9 \mathrm{~h}$ after ischemia. Since our measurements were done in the presence of exogenous cytochrome $\mathrm{c}$, this possibility does not seem to be a plausible explanation of our results. In addition to mitochondrial subunits, Western blot quantification of nuclear-encoded $\mathrm{COXVb}$ did not reveal any ischemia-induced changes at the level of this subunit. In yeast, $\mathrm{COXVb}$ is a hypoxic gene the transcription of which is increased and exclusively expressed under hypoxic conditions and the increase of $\mathrm{COXVb}$ level elevates overall COX activity (Burke and Poyton 1998). However, it seems that in mammals COXVb is transcribed and expressed at high level also under full oxygen availability (Racay et al. 2006). Similarly to $\mathrm{COXVb}$, the level of another nuclear-encoded subunit COXIV was not changed one day after global brain ischemia (Sugawara et al. 1999). The unaltered level of nuclear-encoded subunits, despite strong depression of 
nuclear gene translation observed after global brain ischemia, further supports the view about high stability of COX subunits. On the other hand, we cannot exclude that ischemia-reperfusion does not affect another components of such complex structure of COX. For example, in PC12 cells a $38 \%$ decrease in heme aa3 content was seen after $10 \mathrm{~h}$ of hypoxia, while COX activity was reduced only marginally (Vijayasarathy et al. 2003). In cultured cerebellar granular cells, significant changes in kinetic parameters of COX (decrease of turnover number, increase of Hill coefficient and increase of $\mathrm{K}_{\mathrm{m}}$ of cytochrome c) were documented after $3 \mathrm{~h}$ of hypoxia (Horvat et al. 2006). These changes were attributed to increased expression of COX subunit IV-2 isoform. In gerbil brain, COX activity was not affected by brain ischemia and short-term reperfusion (Almeida et al. 1995). Significant inhibition of COX observed after $120 \mathrm{~min}$ of reperfusion was attributed to free radical production and consequent modification of COX (Almeida et al. 1995). In fact, recent studies have postulated the effect of posttranslational modifications of COX subunits on COX inhibition. Several mechanisms, like nitrosylation, phoshorylation or oxidative modification by free radicals, were documented. One of the hallmarks of brain ischemia-reperfusion injury is overproduction of nitric oxide (Lipton 1999), which induces irreversible inhibition of COX activity (Zhang et al. 2005). In addition, inhibition of COX activity due to either AMP-dependent phosphorylation of COXI (Lee et al. 2005) or modification of COX subunits by hydroxynonenal, product of lipid peroxidation, was documented (Chen et al. 2001, Kaplan et al. 2007). However, structure of COX is extremely complex and its biogenesis involves the coordinated action of two genomes, the three mitochondrial DNA encoded subunits of the catalytic core plus another 10 nuclear DNA encoded subunits and requiring more than 20 additional nuclear-encoded factors (Fontanesi et al. 2006, Stibůrek et al. 2006). Therefore, possible mechanisms associated with observed ischemia-induced decrease of COX activity should be further investigated using comprehensive proteomic approach.

In conclusion, our results showed that ischemiareperfusion affects mitochondrial translation machinery leading to inhibition of mitochondrial protein synthesis in rat hippocampus. Although, mitochondria-encoded core subunits I, II and III of COX are translated in mitochondria, based on our data we suggest that inhibition of COX activity is caused by ischemia-induced modification of COX polypeptides rather than by inhibition of mitochondrial translation. Since whole hippocampi were used in our study, observed inhibition of both mitochondrial protein synthesis and activity of COX seems to be a general result of brain ischemia, affecting also other hippocampal cells than the most vulnerable CA1 pyramidal neurons. We assume that generally observed changes together with CA1 specific alterations, observed by morphological approach (Abe et al. 1993, 1998, Nakatsuka et al. 2000), might significantly aggravate the ischemia-induced mitochondrial dysfunction in these vulnerable neurons.

\section{Conflict of Interest}

There is no conflict of interest.

\section{Acknowledgements}

This work was supported by the Ministry of Education of Slovak Republic (grant 1/4255/07 to P.R.). Authors are grateful to Zdenka Cetlova and Jolana Bencatova for their excellent technical assistance.

\section{References}

ABE K, KAWAGOE J, AOKI M, KOGURE K: Changes of mitochondrial DNA and heat shock protein gene expressions in gerbil hippocampus after transient forebrain ischemia. J Cereb Blood Flow Metab 13: 773-780, 1993.

ABE K, KAWAGOE J, AOKI M, KOGURE K, ITOYAMA Y: Stress protein inductions after brain ischemia. Cell Mol Neurobiol 18: 709-719, 1998.

ALMEIDA A, ALLEN KL, BATES TE, CLARK JB: Effect of reperfusion following cerebral ischaemia on the activity of the mitochondrial respiratory chain in the gerbil brain. $J$ Neurochem 65: 1698-703, 1995.

ALTHAUSEN S, MENGESDORF T, MIES G, OLAH L, NAIRN AC, PROUD CG, PASCHEN W: Changes in the phosphorylation of initiation factor eIF-2alpha, elongation factor eEF-2 and p70 S6 kinase after transient focal cerebral ischaemia in mice. $J$ Neurochem 78: 779-787, 2001. 
BODSCH W, TAKAHASHI K: Selective neuronal vulnerability to cerebral protein- and RNA-synthesis in the hippocampus of the gerbil brain. In: Cerebral Ischemia. A BES, P BRAQUET, R PAOLETTI, BK SIESJÖ BK (eds), Elsevier, Amsterdam, 1984, pp 197-208.

BURDA J, MARTÍN EM, GARCÍA A, ALCÁZAR A, FANDO JL, SALINAS M: Phosphorylation of the $\alpha$ subunit of initiation factor 2 correlates with inhibition of translation following transient cerebral ischaemia in the rat. Biochem. J 302: 335-338, 1994.

BURKE PV, POYTON RO: Structure/function of oxygen-regulated isoforms in cytochrome c oxidase. J Exp Biol 201: 1163-75, 1998.

CAO G, CLARK RS, PEI W, YIN W, ZHANG F, SUN FY, GRAHAM SH, CHEN J: Translocation of apoptosisinducing factor in vulnerable neurons after transient cerebral ischemia and in neuronal cultures after oxygenglucose deprivation. J Cereb Blood Flow Metab 23: 1137-1150, 2003.

CHARRIAUT-MARLANGUE C, AGGOUN-ZOUAOUI D, REPRESA A, BEN-ARI Y: Apoptotic features of selective neuronal death in ischemia, epilepsy and gp 120 toxicity. Trends Neurosci 19: 109-114, 1996.

CHEN J, HENDERSON GI, FREEMAN GL: Role of 4-hydroxynonenal in modification of cytochrome c oxidase in ischemia/reperfused rat heart. J Mol Cell Cardiol 33: 1919-1927, 2001.

CHOMCZYNSKI P: One-hour downward alkaline capillary transfer for blotting of DNA and RNA. Anal Biochem 201: 134-139, 1992.

CHOMYN A, ENRIQUEZ JA, MICOL V, FERNANDEZ-SILVA P, ATTARDI G: The mitochondrial myopathy, encephalopathy, lactic acidosis, and stroke-like episode syndrome-associated human mitochondrial tRNALeu (UUR) mutation causes aminoacylation deficiency and concomitant reduced association of mRNA with ribosomes. J Biol Chem 275: 19198-19209, 2000.

CLAYTON R, CLARK JB, SHARPE M: Cytochrome c release from rat brain mitochondria is proportional to the mitochondrial functional deficit: implications for apoptosis and neurodegenerative disease. J Neurochem $\mathbf{9 2}$ : 840-849, 2005.

DEGRACIA DJ, NEUMAR RW, WHITE BC, KRAUSE GS: Global brain ischemia and reperfusion: Modification in eukaryotic factors associated with inhibition of translation initiation. J Neurochem 67: 2005-2012, 1996.

DEGRACIA DJ, KUMAR R, OWEN CR, KRAUSE GS, WHITE BC: Molecular pathways of protein synthesis inhibition during brain reperfusion: implications for neuronal survival or death. J Cereb Blood Flow Metab 22: 127-141, 2002.

ENDO H, KAMADA H, NITO C, NISHI T, CHAN PH: Mitochondrial translocation of p53 mediates release of cytochrome c and hippocampal CA1 neuronal death after transient global cerebral ischemia in rats. $J$ Neurosci 26: 7974-7983, 2006.

FISKUM G: Mitochondrial participation in ischemic and traumatic neural cell death. J Neurotrauma 17: 843-855, 2000.

FONTANESI F, SOTO IC, HORN D, BARRIENTOS A: Assembly of mitochondrial cytochrome c-oxidase, a complicated and highly regulated cellular process. Am J Physiol 291: C1129-C1147, 2006.

GARCIA L, O'LOGHLEN A, MARTIN ME, BURDA J, SALINAS M: Does phosphorylation of eukaryotic elongation factor eEF2 regulate protein synthesis in ischemic preconditioning? J Neurosci Res 77: 292-298, 2004.

HONKAINIEMI J, MASSA SM, BRECKINRIDGE M, SHARP FR: Global ischemia induces apoptosis-associated genes in hippocampus. Mol Brain Res 42: 79-88, 1996.

HORI O, ICHINODA F, TAMATANI T, YAMAGUCHI A, SATO N, OZAWA K, KITAO Y, MIYAZAKI M, HARDING HP, RON D, TOHYAMA MM, STERN D, OGAWA S: Transmission of cell stress from endoplasmic reticulum to mitochondria: enhanced expression of Lon protease. J Cell Biol 157: 1151-1160, 2002.

HORVAT S, BEYER C, ARNOLD S: Effect of hypoxia on the transcription pattern of subunit isoforms and the kinetics of cytochrome c oxidase in cortical astrocytes and cerebellar neurons. J Neurochem 99: 937-951, 2006.

HOSSMANN KA: Disturbances of cerebral protein synthesis and ischemic cell death. Prog Brain Res 96: 161-177, 1993. 
HU BR, WIELOCH T: Stress-induced inhibition of protein synthesis initiation: modulation of initiation factor 2 and guanine nucleotide exchange factor activities following transient cerebral ischemia in the rat. $J$ Neurosci 13: 1830-1838, 1993.

KAPLAN P, TATARKOVÁ Z, RACAY P, LEHOTSKÝ J, PAULIKOVÁ M, DOBROTA D: Oxidative modifications of cardiac mitochondria and inhibition of cytochrome c oxidase activity by 4-hydroxynonenal. Redox Rep 12 : 211-218, 2007.

KAPP LD, LORSCH JR: The molecular mechanics of eukaryotic translation. Annu Rev Biochem 73: 657-704, 2004.

KIESSLING M, DIENEL GA, JACEWICZ M, PULSINELLI WA: Protein synthesis in postischemic rat brain: a twodimensional electrophoretic analysis. J Cereb Blood Flow Metab 6: 642-649, 1986.

KRAJEWSKI S, KRAJEWSKA M, ELLERBY LM, WELSH K, XIE Y, DEVERAUX OL, SALVESEN GS, BREDESEN DE, ROSENTHAL RE, FISKUM G, REED JC: Release of caspase-9 from mitochondria during neuronal apoptosis and cerebral ischemia. Proc Natl Acad Sci USA 96: 5752-5757, 1999.

LEE CP, SCIAMANNA M, PETERSON PL: Intact rat brain mitochondria from a single animal: preparation and properties. Methods Toxicol 2: 41-49, 1993.

LEE I, SALOMON AR, FICARRO S, MATHES I, LOTTSPEICH F, GROSSMAN LI, HUTTEMANN M: cAMPdependent tyrosine phosphorylation of subunit I inhibits cytochrome c oxidase activity. $J$ Biol Chem 280: 6094-6100, 2005.

LIPTON P: Ischemic cell death in brain neurons. Physiol Rev 79: 1431-1568, 1999.

MA L, SPREMULLI LL: Cloning and sequence analysis of the human mitochondrial translational initiation factor 2 cDNA. J Biol Chem 270: 1859-1865, 1995.

MARTIN DE LA VEGA C, BURDA J, NEMETHOVA M, QUEVEDO C, ALCAZAR A, MARTIN ME, DANIELISOVA V, FANDO JL, SALINAS M: Possible mechanisms involved in the down-regulation of translation during transient global ischaemia in the rat brain. Biochem J 357: 819-826, 2001.

MCKEE EE, GRIER BL, THOMPSON GS, MCCOURT JD: Isolation and incubation conditions to study heart mitochondrial protein synthesis. Am J Physiol 258: E492-E502, 1990.

MENGESDORF T, PROUD CG, MIES G, PASCHEN W: Mechanisms underlying suppression of protein synthesis induced by transient focal cerebral ischemia in mouse brain. Exp Neurol 177: 538-546, 2002.

NAKATSUKA H, OHTA S, TANAKA J, TOKU K, KUMON Y, MAEDA N, SAKANAKA M, SAKAKI S: Histochemical cytochrome c oxidase activity and caspase-3 in gerbil hippocampal CA1 neurons after transient forebrain ischemia. Neurosci Lett 285: 127-130, 2000.

NICHOLLS DG, BUDD SL: Mitochondria and neuronal survival. Physiol Rev 80: 315-360, 2000.

NITATORI T, SATO N, WAGURI S, KARASAWA Z, ARAKI H, SHIBANAI K, KOMINAMI E, UCHIYAMA Y: Delayed neuronal death in the CA1 pyramidal cell layer of the gerbil hippocampus following transient ischemia is apoptosis. $J$ Neurosci 15: 1001-1011, 1995.

NEUMAR RW, DEGRACIA DJ, KONKOLY LL, KHOURY JI, WHITE BC, KRAUSE GS: Calpain mediates eukaryotic initiation factor $4 \mathrm{G}$ degradation during global brain ischemia. J Cereb Blood Flow Metab 18: 876$881,1998$.

NEUMAR RW, DEGRACIA DJ, WHITE BC, MCDERMOTT PJ, EVANS DR, KRAUSE GS: Eukaryotic initiation factor 4E degradation during brain ischemia. J Neurochem 65: 1391-1394, 1995.

NOWAK TS JR: Protein synthesis and the heat shock/stress response after ischemia. Cerebrovasc Brain Metab Rev 2: 345-366, 1990.

PASCHEN W, DOUTHEIL J: Disturbances of the functioning of endoplasmic reticulum: a key mechanism underlying neuronal cell injury? J Cereb Blood Flow Metab 19: 1-18, 1999.

PEREZ-PINZON MA, XU GP, BORN J, LORENYO J, BUSTO R, ROSENTHAL M, SICK TJ: Cytochrome C is released from mitochondria into the cytosol after cerebral anoxia or ischemia. J Cereb Blood Flow Metab 19: 39-43, 1999.

PERIER C, TIEU K, GUEGAN C, CASPERSEN C, JACKSON-LEWIS V, CARELLI V, MARTINUZZI A, HIRANO M, PRZEDBORSKI S, VILA M: Complex I deficiency primes Bax-dependent neuronal apoptosis through mitochondrial oxidative damage. Proc Natl Acad Sci USA 102: 19126-19131, 2005. 
POLOSA PL, ATTARDI G: Distinctive pattern and translational control of mitochondrial protein synthesis in rat brain synaptic endings. J Biol Chem 266: 10011-10017, 1991.

POLSTER BM, FISKUM G: Mitochondrial mechanisms of neural cell apoptosis. J Neurochem 90: 1281-1289, 2004.

RACAY P, GREGORY P, SCHWALLER B: Parvalbumin deficiency in fast-twitch muscles leads to increased 'slowtwitch type' mitochondria, but does not affect the expression of fiber specific proteins. FEBS $J$ 273: 96-108, 2006.

RAMACHANDRAN A, MOELLERING DR, CEASER E, SHIVA S, XU J, DARLEY-USMAR V: Inhibition of mitochondrial protein synthesis results in increased endothelial cell susceptibility to nitric oxide-induced apoptosis. Proc Natl Acad Sci USA 99: 6643-6648, 2002.

SMEITINK J, VAN DEN HEUVEL L, DIMAURO S: The genetics and pathology of oxidative phosphorylation. Nat Rev Genet 2: 342-352, 2001.

SMIALEK M, HAMBERGER A: The effect of moderate hypoxia and ischemia on cytochrome oxidase activity and protein synthesis in brain mitochondria. Brain Res 17: 369-371, 1970.

STIBU゚REK L, HANSÍKOVÁ H, TESAŘOVÁ M, ČERNÁ L, ZEMAN J: Biogenesis of eukaryotic cytochrome c oxidase. Physiol Res 55 (Suppl 2): S27-S41, 2006.

SUGAWARA T, FUJIMURA M, MORITA-FUJIMURA Y, KAWASE M, CHAN PH: Mitochondrial release of cytochrome c corresponds to the selective vulnerability of hippocampal CA1 neurons in rats after transient global cerebral ischemia. $J$ Neurosci 19: 1-6, 1999.

TAANMAN J-W: The mitochondrial genome: structure, transcription, translation and replication. Biochem Biophys Acta 1410: 103-123, 1999.

THILMANN R, XIE Y, KLEIHUES P, KIESSLING M: Persistent inhibition of protein synthesis precedes delayed neuronal death in postischemic gerbil hippocampus. Acta Neuropathol (Berl) 71: 88-93, 1986.

TRYOEN-TOTH P, RICHERT S, SOHM B, MINE M, MARSAC C, VAN DORSSELAER A, LEIZE E, FLORENTZ $\mathrm{C}$ : Proteomic consequences of a human mitochondrial tRNA mutation beyond the frame of mitochondrial translation. J Biol Chem 278: 24314-24323, 2003.

VIJAYASARATHY C, DAMLE S, PRABU SK, OTTO CM, AVADHANI NG: Adaptive changes in the expression of nuclear and mitochondrial encoded subunits of cytochrome c oxidase and the catalytic activity during hypoxia. Eur J Biochem 270: 871-879, 2003.

WALLACE DC: Mitochondrial disease in man and mouse. Science 283: 1482-1488, 1999.

ZHANG J, JIN B, LI L, BLOCK ER, PATEL JM: Nitric oxide-induced persistent inhibition and nitrosylation of active site cysteine residues of mitochondrial cytochrome-c oxidase in lung endothelial cells. Am J Physiol 288: C840-C849, 2005. 